\title{
DOI: 10.7596/taksad.v6i4.1173
}

Citation: Kuksin, I., Markhgeym, M., Novikova, A., Samsonov, V., \& Tonkov, E. (2017). Constitutional Hypostases of Citizenship of the West European Countries. Journal of History Culture and Art Research, 6(4), 286-295. doi:http://dx.doi.org/10.7596/taksad.v6i4.1173

\section{Constitutional Hypostases of Citizenship of the West European Countries}

\author{
Ivan N. Kuksin ${ }^{1}$, Marina V. Markhgeym² \\ Alevtina E. Novikova ${ }^{3}$, Valerij N. Samsonov ${ }^{4}$, Evgeniy E. Tonkov ${ }^{5}$
}

\begin{abstract}
In this article, citizenship is considered in its various forms, based on a comparative legal analysis of the texts from the constitutions of Western European countries, taking into account doctrinal developments and the influence of various social phenomena and processes. Being derived from the sovereign public will, citizenship in the constitutional legal doctrine is traditionally treated as a stable legal relationship between a person and a state, expressed in the aggregate of their mutual rights and obligations. An analysis of the constitutional texts of Western European countries showed that citizenship was enshrined in them as a legal relationship, which parties could be states, as well as a state and an individual; citizenship was also enshrined as a constitutional-legal institution with varying degrees of structural and compositional concentration of its norms, as an independent law and a condition for the exercise of other constitutional rights, freedoms and duties. Typical and special constitutional features of the citizenship of Western European countries are shown.
\end{abstract}

Keywords: Citizenship, Nationality, Constitution, Legal status, Human rights, Sovereignty, State.

\footnotetext{
${ }^{1}$ Belgorod State University 85, Pobedy str., Belgorod, 308015.

${ }^{2}$ Belgorod State University 85, Pobedy str., Belgorod, 308015. E-mail: markheim@bsu.edu.ru

${ }^{3}$ Belgorod State University 85, Pobedy str., Belgorod, 308015.

${ }^{4}$ Belgorod State University 85, Pobedy str., Belgorod, 308015.

${ }^{5}$ Belgorod State University 85, Pobedy str., Belgorod, 308015.
} 


\section{Introduction}

Citizenship refers to those capacious legal phenomena, the essence, the features and content of which, while continuing to be of interest for scientists, grow, refined, and revised through the prism of other social phenomena and processes. The analysis of doctrinal sources has shown that theoretical aspects of citizenship [1, 2, 3] and factors of its transformation continue to be developed $[4,5,6,7]$. New characteristics $[8,9,10,11,12]$ and the contexts of the study of citizenship are revealed [13,14]. Although citizenship is associated traditionally with a state $[15,16,17,18]$, in modern works it is also associated with a group of countries [19].

Citizenship is applied to the constitutional characteristics of both the state and the legal position of a person. This, together with the sovereign public will, determines its constitutional diversity.

Citizenship has both doctrinal and legal definitions. The constitutional theory treats citizenship, for example, through the person's belonging to a "state" [20, p. 35] and to "the people of a state" [21, p. 81]; through national identity [22, p. 155; 23]; through the legal registration of the population of a state and the attribute of state sovereignty [24, p. 81], through interfacing with the legal provision of constitutional protection of persons under the jurisdiction of a state [25, p.70-73]. Legislative versions of citizenship are reduced mainly to a stable legal connection between a citizen and a state, which is expressed in the corresponding mutual rights and obligations inherent to the parties.

\section{Methodology}

The work was based on the dialectical approach to the study of legal phenomena and processes using general scientific (system, logical, analysis and synthesis) and particularscientific methods. Among the latter are formal-legal, linguistic-legal, and comparative-legal, which were collectively used to study the phenomenon of citizenship in its various constitutional hypostases. The focus group comprised 22 Western European states which constitutions were taken from the Internet library "Constitutions of the states (countries) of the world" (http://worldconstitutions.ru/). The choice of this focus group is conditioned by the different forms of government - 10 monarchies (Andorra, Belgium, Denmark, Spain, Liechtenstein, Luxembourg, Monaco, Netherlands, Norway, Sweden) and 12 republics (Austria, Germany, Greece, Ireland, Iceland, Italy, Portugal, San Marino, Finland, France, Switzerland). Such a difference allows one to expect a variety of states' approaches to enshrine issues of Citizenship, which can be referred to as Nationality. 


\section{Results and discussion}

Let us illustrate some of the revealed constitutional features of citizenship beginning with conceptual preferences. Thus, Article 8 of the Belgian Constitution establishes that "Belgian nationality is acquired, retained and lost on the basis of orders established by civil law". However, this is rather an exception, since in other monarchies the preference is given to the term "citizenship". Thus, the Constitution of the Spanish Kingdom stipulates that "Spanish citizenship is acquired, retained and lost in accordance with law" (Part 1, Article 11). The Constitution of the Principality of Liechtenstein stipulates that "Acquisition and loss of citizenship are regulated by law" (Article 30); the Constitution of the Kingdom of the Netherlands: "Citizenship of the Netherlands is governed by the Act of Parliament" (Part 1, Article 2), the Constitution of the Kingdom of Sweden: "The law regulates... questions on: 1) Swedish citizenship..." (§ 2, Ch. 8).

The integral version is implemented in $\S 92$ of the Constitution of the Norwegian Kingdom where both "national subjects" (a) and "Norwegian citizenship" are mentioned (paragraph d).

The "citizenship-nationality" matter is articulated originally in article 9 (1) of the Constitution of the Grand Duchy of Luxembourg "The merit of a Luxembourger is acquired, preserved and lost in accordance with the norms established by civil legislation".

From the above-mentioned constitutional characteristics it follows that the relations concerning citizenship are regulated and specified in the legislative order.

The next hypostasis of citizenship is its interpretation as a legal relationship. In one case, its parties may be the states that agree on, for example, the procedure for resolving conflicts of laws on citizenship [26], a reduction of statelessness, the citizenship of a married woman, the settlement of multiple citizenship [29], or dual citizenship [30]. With regard to the latter, we clarify that in Part 3, Article 11 of the Constitution of Spain it is expressly stated that "the State can conclude treaties on dual citizenship with Ibero-American countries or with countries that had or have special relations with Spain". This makes it possible for us to nominate such a legal relationship as constitutional-contractual. There is another approach. Thus, Article 27 of the Constitution of Malta is illustratively called as "Prohibition of dual citizenship" and describes in some detail all possible cases and corresponding behavior of a citizen and the state in this connection.

In connection with the reduction of statelessness (this is how this state in international acts should be written and called), we note that in Article 16 of the German Constitution it is established: "Loss of citizenship can only follow on the basis of the law, and against the will of the person concerned, only in that case if he or she does not become a stateless person". 
Considering citizenship as a legal relationship, we recall that its parties are not only states (public entities), but also a state and a citizen. This legal relationship is regulated by the norms of the Constitution and legislative norms, which makes it possible to define it as constitutional and legal. For example, the Constitution of the Republic of Austria stipulates that "Single citizenship is established for the Republic of Austria" (Part 1, Article 6), "Legislation belongs to the jurisdiction of the Federation, and executive jurisdiction belongs to Lands on the following issues: 1) citizenship..." (Part 1, Article 11); The Basic Law of Germany stipulates that: "German citizenship cannot be taken away. Loss of citizenship can follow only on the basis of the law..." (Item 1, Article 16), "The Federation has exclusive legislative competence on the following issues:... 2) Federation citizenship..." (Article 73); the Constitution of France stipulates: "The law establishes standards relating to:... citizenship" (Art.34). The Constitution of the Principality of Monaco establishes that "Monegasques are all persons born in Monaco or abroad from a father-Monegasque. The law specifies other ways of obtaining citizenship. The law regulates the conditions for the deprivation of citizenship obtained through naturalization" (Art.18 of Title III). Interpretation of this rule gives grounds for at least two conclusions. Firstly, the state gives priority to nature of the citizenship of Monaco by blood. Secondly, the born citizens, unlike the naturalized, cannot be deprived of the citizenship of Monaco, what emphasizes the differences in their legal status.

The next hypostasis of citizenship is the constitutional institution. We believe reasonable the words of G.V. Maltsev that an institute is "a multi-faceted social structure created on a normative basis, capable of acting in a different format, uniting by its action all or nearly all of society or the state as a whole" [31, p. 390]. The Institute of Citizenship is treated as a set of constitutional norms related to citizenship. In some constitutions, these norms are concentrated in the corresponding composition part, in others they are dispersed. An example of the first constitutional approach is Andorra (Chapter II on Andorran citizenship), Malta (Chapter III. Citizenship), Portugal (Article 4. Portuguese citizenship), Finland (§ 5. Finnish citizenship), Switzerland (Article 37. Rights of Citizenship; Article 38. Acquisition and loss of citizenship rights). Examples of the latter are the constitutional norms of Ireland (art. 9), Iceland (art. 20, 33, 66), Spain (art. 11), Monaco (art. 15, 18, 75, 77). They indicate the principles of citizenship, ways of obtaining it, change, and loss, etc.

In constitutional-legal theory, citizenship is treated both as an independent law and as a law related to other rights, freedoms and duties. Similar manifestations of citizenship are also found in the constitutions of the group of countries under study. For example, the right to a citizenship is enshrined, for example, in Article 29 of the Constitution of the Principality of Liechtenstein. "Everyone, being a citizen of the state, will have all the rights of citizenship in 
accordance with the provisions of the Constitution", in Article 26 "Other personal rights" of the Constitution of Portugal "1. Everyone is recognized as having... citizenship...", in Article 37 "Rights of citizenship" of the Constitution of Switzerland "1. A Swiss citizen or female citizen is the one who (he or she) has the right to the citizenship of the community and the right to citizenship of the canton. 2. Nobody should be given preference or infliction on damage because of his or her citizenship rights". In the latter case, let us bring this into view that the sex belonging to a person who has Swiss citizenship should be taken into account. A similar approach has been implemented only in the constitutions of Austria (Part 4, Article 9 "Austrian female citizens voluntarily can serve in the federal armed forces and have the right to leave it") and Malta (Part 4, Article 23 "Any woman... must have the right to petition... for taking oath of allegiance to be registered as a female citizen of Malta").

Citizenship as a condition for the exercise of rights and duties is most evident in the public sphere: the suffrage, as well as the obligation to protect fatherland, is traditionally addressed to citizens of a state. An analysis of the constitutional texts of Western European countries made it possible to identify two variants of such a coupling. The first is connected with the general legal status of a person, the second with his or her special status. By way of illustration of the first constitutional option, we cite Part 4 of Article 26 of the Austrian Constitution ("All men and women who are eligible for Austrian citizenship on the election day and who were 19 years old by January 1, are eligible to be elected"); Article 116 of the German Constitution ("(1) The German, in the sense of this Basic Law, is, unless otherwise provided by law, the one who possesses German citizenship..."). With a general legal status, but in an authoritative manner, citizenship is reflected in Article 9 of the Constitution of Ireland ("3. No person shall be deprived of the nationality and citizenship of Ireland on the grounds of sex") and Article 22 of the Constitution of Italy ("No one shall be politically deprived of his/her legal status and capacity, citizenship, and his/her name"). Consequently, citizenship, among other things, is the object of constitutional protection.

An illustration of the second constitutional option is article 31 of the Constitution of Greece ("A Greek citizen who is in this citizenship for at least five years, having the father being a Greek citizen; who has reached the age of forty and has the right to elect, may be elected as the President of the Republic"); Article 20 of the Constitution of Ireland ("The President appoints public officials in accordance with the law. A state post can only be held by a person who has Irish citizenship"); Article 107 of the Constitution of Liechtenstein ("To exercise of any public office in the State of Liechtenstein, it is necessary to be a citizen of Liechtenstein, regardless of other requirements provided for by the Constitution..."); Article 107 of the Constitution of Luxembourg ("(4)... The requirements for citizenship to be met by members 
of the Collegium of the Bourg-Mister and Escheven are established by law...") § 125 of the Constitution of Finland ("... only Finnish citizens may be appointed to certain public offices or to carry out instructions. The general principles for appointing civil servants are competence, ability and proven civil integrity"); $\S 9$ of Chapter 11 of the Constitution of Sweden ("Only a person who is a Swedish citizen can perform the duty and hold office in a court directly responsible to the Government, to hold office or the post of head of a body directly subordinate to the Riksdag or the Government, or a member of such body or its board, or position in the governmental establishment directly subordinate to a minister, or the post of Swedish diplomatic representative... ").

In the above constitutional dispositions, citizenship is not only an attribute of special legal statuses (president, civil servant, judge, others), but also by qualification requirement.

If we summarize, an analysis of doctrinal sources has shown that citizenship, as an object of legal research, is developed in a classical manner and in conjunction with various social phenomena and processes. The increment of knowledge about citizenship is connected both with new trends in state construction, and with comparative legal interpretations of constitutional provisions that allow us to disclose known and identify its additional facets.

\section{Conclusion}

The constitutional aspects of the citizenship of Western European countries are derived from their sovereign public will, manifested in terminology (citizenship / nationality) preferences, structural and compositional (concentrated presentation in an article, group of articles / dispersal over the constitutional text) decisions, status (in relation to general / special constitutional status) and other conjunctions. In addition, citizenship is enshrined in the constitutional texts of Western European countries as an object of legal protection, as a condition for establishing preferences and as a qualification for access to public office.

Being an attribute of a state, citizenship is an object of constitutional-legal (in legal relationships "state-citizen") and contractual-legal (in legal relations "state-state") regulation. States, at their own sovereign discretion, determine the features, parameters, peculiarities and other characteristics of their citizenship.

\section{Footnotes}

1. Turner, B. S. (1993). Contemporary problems in the theory of citizenship. Citizenship and social theory, 1-18. 
2. Oliver, D., \& Heater, D. B. (1994). The foundations of citizenship. Harvester/Wheatsheaf.

3. Heater, D. (2013). What is citizenship?. John Wiley \& Sons.

4. Ong, A. (2006). Neoliberalism as exception: Mutations in citizenship and sovereignty. Duke University Press.

5. Joppke, C. (2007). Transformation of citizenship: status, rights, identity. Citizenship studies, 11(1), 37-48.

6. Jacobs, D., \& Rea, A. (2007). The end of national models?: integration courses and citizenship trajectories in Europe. International Journal on Multicultural Societies (IJMS), 9(2), 264-283.

7. Joppke, C. (1999). How immigration is changing citizenship: a comparative view. Ethnic and racial studies, 22(4), 629-652.

8. Ong, A. (1999). Flexible citizenship: The cultural logics of transnationality. Duke University Press.

9. Dower, N., \& Williams, J. (2003). An introduction to global citizenship (Vol. 7, pp. 2129). Edinburgh: Edinburgh University Press.

10. Lister, R. (2007). Inclusive citizenship: Realizing the potential 1. Citizenship studies, 11(1), 49-61.

11. Laguerre, M. S. (2016). Diasporic Citizenship: Haitian Americans in Transnational America. Springer.

12. Bauböck, R. (1994). Transnational citizenship.

13. Aleinikoff, T. A., \& Klusmeyer, D. (Eds.). (2010). Citizenship today: global perspectives and practices. Brookings Institution Press.

14. Kofman, E. (2005). Citizenship, migration and the reassertion of national identity. Citizenship studies, 9(5), 453-467.

15. Brubaker, R. (2009). Citizenship and nationhood in France and Germany. Harvard University Press.

16. Shklar, J. N. (1991). American citizenship: The quest for inclusion (Vol. 3). Harvard University Press.

17. Pattie, C., Seyd, P., \& Whiteley, P. (2004). Citizenship in Britain: Values, participation and democracy. Cambridge University Press.

18. Favell, A. (2016). Philosophies of integration: immigration and the idea of citizenship in France and Britain. Springer.

19. Howard, M. M. (2009). The politics of citizenship in Europe. Cambridge University Press. 
20. Maltsev, G. V. (1968). The Problem of personality in Soviet law. Soviet state and law, 4. (InRussian)

21. Kutafin, O. E. (2003). Russian citizenship. M.: Yurist. (In Russian)

22. Habermas, J. (2003). Citizenship and national identity (Vol. 3) Globalization: Global membership and participation.

23. Isin, E. F., \& Wood, P. K. (1999). Citizenship and identity (Vol. 448). Sage

24. Vitruk, N. V. (2008). The General theory of the legal status of the individual. M.: Norma. (In Russian)

25. Markhgeym, M.V. (2005). Protection of human rights and freedoms in modern Russia: a systemic constitutional model, the problems of its functioning and improvement. Rostovon-Don. (In Russian)

26. Convention On Certain Questions Relating To The Conflict Of Nationality Laws (The Hague, 12 April 1930) // http://eudo-citizenship.eu

27. Convention on the reduction of statelessness. Adopted by the UN General Assembly on 30 August 1961 http://legal.un.org/ilc/texts/instruments/english/conventions/6_1_1961.pdf

28. Convention on the nationality of married women of 29 January 1957// http://www.humanrights.is/static/files/Itarefni/convention-on-the-nationality-of-marriedwomen.pdf

29. Convention on the reduction of cases of multiple nationality and military obligations in cases of multiple nationality (Strasbourg, 6 may 1963) // http://www.legislationline.org/ru/documents/action/popup/id/14443

30. Hansen, R., \& Weil, P. (2002). Dual nationality, social rights and federal citizenship in the US and Europe: The reinvention of citizenship. Berghahn books.

31. Maltsev, G. V. (2007) The Social foundations of law. M., Norma. (In Russian).

\section{References}

Aleinikoff, T. A. \& Klusmeyer, D. (Eds.). (2010). Citizenship today: global perspectives and practices. Brookings Institution Press.

Bauböck, R. (1994). Transnational citizenship.

Brubaker, R. (2009). Citizenship and nationhood in France and Germany. Harvard University Press. 
Convention on Certain Questions Relating to the Conflict of Nationality Laws (The Hague, 12 April 1930) // http://eudo-citizenship.eu

Convention on the nationality of married women of 29 January 1957// http://www.humanrights.is/static/files/Itarefni/convention-on-the-nationality-of-marriedwomen.pdf

Convention on the reduction of cases of multiple nationality and military obligations in cases of multiple nationality (Strasbourg, 6 may 1963) // http://www.legislationline.org/ru/documents/action/popup/id/14443

Convention on the reduction of statelessness. Adopted by the UN General Assembly on 30 August 1961 // http://legal.un.org/ilc/texts/instruments/english/conventions/6_1_1961.pdf

Dower, N. \& Williams, J. (2003). An introduction to global citizenship (Vol. 7, pp. 21-29). Edinburgh: Edinburgh University Press.

Favell, A. (2016). Philosophies of integration: immigration and the idea of citizenship in France and Britain. Springer.

Habermas, J. (2003). Citizenship and national identity (Vol. 3) Globalization: Global membership and participation.

Hansen, R. \& Weil, P. (2002). Dual nationality, social rights and federal citizenship in the US and Europe: The reinvention of citizenship. Berghahn books.

Heater, D. (2013). What is citizenship? John Wiley \& Sons.

Howard, M. M. (2009). The politics of citizenship in Europe. Cambridge University Press.

Isin, E. F. \& Wood, P. K. (1999). Citizenship and identity (Vol. 448). Sage.

Jacobs, D. \& Rea, A. (2007). The end of national models? Integration courses and citizenship trajectories in Europe. International Journal on Multicultural Societies (IJMS), 9(2), 264-283.

Joppke, C. (1999). How immigration is changing citizenship: a comparative view. Ethnic and racial studies, 22(4), 629-652.

Joppke, C. (2007). Transformation of citizenship: status, rights, identity. Citizenship studies, 11(1), 37-48.

Kofman, E. (2005). Citizenship, migration and the reassertion of national identity. Citizenship studies, 9(5), 453-467.

Kutafin, O. E. (2003). Russian citizenship. M.: Yurist. (In Russian)

Laguerre, M. S. (2016). Diasporic Citizenship: Haitian Americans in Transnational America. Springer.

Lister, R. (2007). Inclusive citizenship: Realizing the potential 1. Citizenship studies, 11(1), 49-61. 
Maltsev, G. V. (1968). The Problem of personality in Soviet law. Soviet state and law, 4. (In Russian)

Maltsev, G. V. (2007) The Social foundations of law. M., Norma. (In Russian)

Markhgeym, M. V. (2005). Protection of human rights and freedoms in modern Russia: a systemic constitutional model, the problems of its functioning and improvement. Rostov-onDon. (In Russian)

Oliver, D. \& Heater, D. B. (1994). The foundations of citizenship. Harvester/Wheatsheaf. Ong, A. (1999). Flexible citizenship: The cultural logics of transnationality. Duke University Press.

Ong, A. (2006). Neoliberalism as exception: Mutations in citizenship and sovereignty. Duke University Press.

Pattie, C.; Seyd, P. \& Whiteley, P. (2004). Citizenship in Britain: Values, participation and democracy. Cambridge University Press.

Shklar, J. N. (1991). American citizenship: The quest for inclusion (Vol. 3). Harvard University Press.

Turner, B. S. (1993). Contemporary problems in the theory of citizenship. Citizenship and social theory, 1-18.

Vitruk, N. V. (2008). The General theory of the legal status of the individual. M.: Norma. (In Russian). 